\title{
Correction to: Summer phyto- and bacterioplankton communities during low and high productivity scenarios in the Western Antarctic Peninsula
}

\author{
Sebastián Fuentes ${ }^{1,2}$ - José Ignacio Arroyo ${ }^{1,2}$. Susana Rodriguez-Marconi ${ }^{3,4}$. Italo Masotti ${ }^{3}$. \\ Tomás Alarcon-Schumacher ${ }^{1,2} \cdot$ Martin F. Polz $^{5} \cdot$ Nicole Trefault $^{6} \cdot$ Rodrigo De la Iglesia $^{1} \cdot$ Beatriz Díez $^{1,2}$
}

Published online: 7 July 2021

(c) Springer-Verlag GmbH Germany, part of Springer Nature 2021

\section{Correction to: Polar Biology (2019) 42:159-169 https://doi.org/10.1007/s00300-018-2411-5}

The authors regret that in the original publication of "Summer phyto- and bacterioplankton communities during low and high productivity scenarios in the Western Antarctic Peninsula", the Acknowledgements were incomplete, and they provide this completed version:

The authors gratefully acknowledge the Armada de Chile staff at Arturo Prat Station and the staff from the Chilean Antarctic Institute (INACH); their support made possible the sampling in Chile Bay. The study used data that have been collected and analysed by Beatriz Fernández in the course of her postdoctoral project (Fondecyt Postdoctoral No 3140422 [2014-2016]). The authors also thank the Department of

The original article can be found online at https://doi.org/10.1007/ s00300-018-2411-5.

Beatriz Díez

bdiez@bio.puc.cl

1 Department of Molecular Genetics and Microbiology, Faculty of Biological Sciences, Pontifcia Universidad Católica de Chile, Santiago, Chile

2 Center for Climate and Resilience Research (CR)2, Santiago, Chile

3 Facultad de Ciencias del Mar y de Recursos Naturales, Universidad de Valparaíso, Viña del Mar, Chile

4 Programa de Magister en Oceanografía, Universidad de Valparaíso - Pontifcia Universidad Católica de Valparaíso, Valparaiso, Chile

5 Department of Civil and Environmental Engineering, Massachusetts Institute of Technology, Cambridge, MA, USA

6 Center for Genomics and Bioinformatics, Faculty of Sciences, Universidad Mayor, Santiago, Chile
Climatology, Centro Meteorológico de Valparaíso, Armada de Chile, for the meteorological data and María Estrella Alcamán, Cynthia Sanhueza, Laura Farías and Josefa Verdugo for their assistance with sample collection.

Publisher's Note Springer Nature remains neutral with regard to jurisdictional claims in published maps and institutional affiliations. 